\title{
Introducing Volume 13 of Regenerative Medicine
}

\author{
Adam Price-Evans*,1 \\ ${ }^{1}$ Future Science Group, Unitec House, 2 Albert Place, London N3 1QB, UK \\ * Author for correspondence: a.price-evans@futuremedicine.com
}

First draft submitted: 15 November 2017; Accepted for publication: 15 November 2017; Published online: 24 January 2018

Keywords: Award for Cultivating Excellence $\bullet$ clinical trial $\bullet$ degeneration $\bullet$ disease $\bullet$ fake news $\bullet$ regeneration $\bullet$ regenerative medicine $\bullet$ stem cell $\bullet$ transplantation

To all of our readers, I would like to begin 2018 by wishing you a happy new year and by introducing you to the 13th volume of Regenerative Medicine. In this foreword I will present some selected highlights from 2017 in addition to looking forward to the year ahead.

\section{Content highlights in 2017}

Regenerative Medicine ended 2016 with a 10-year anniversary Special Focus Issue entitled, "Regenerative medicine: past, present and future" [1], which reflected on how the field changed over the previous decade and offered perspectives on the progress being made in the field. Moving on from that, our aim was to continue showcasing the latest research and expert commentary from leaders in the field and in 2017, Regenerative Medicine did just that. In Volume 12, a large number of high-impact and insightful articles were published in the journal across a wide range of topics within the ever-evolving field of regenerative medicine.

At the time of writing, the most read article of 2017 in Regenerative Medicine is a Special Report entitled, "Regenerative capacity of autologous stem cell transplantation in elderly: a report of biomedical outcomes" [2]. In this article, the authors analyze whether self-renewal potential, expression of stemness genes and in vitro differentiation capability in stem cells collected from elderly patients validate their application in clinical trials.

The second most read article of 2017 and most read Editorial was "Mesenchymal stem cells in regenerative medicine: a new paradigm for degenerative bone diseases" [3]. In this short article, the authors discuss the translational potential of mesenchymal stem cells for bone and cartilage disease and offer their perspectives on what issues must be overcome in order to realize the potential of mesenchymal stem cells and make them a useful resource in clinical therapeutics in the future.

The most highly read Research Article published in Volume 12 was "Fake news portrayals of stem cells and stem cell research" [4]. The article uses content analysis to examine how stem cell research is portrayed on websites flagged as 'fake' or 'junk science' news. The authors reveal several observations relating to misinformation, bias, promotion of mistrust and exaggeration and offer a 'call to action' for the research community and governments to work to curtail the influence of these websites.

Following the theme of online sources of information on stem cell research, another highly popular article from this volume and our top-scoring paper on the Altmetric platform in 2017 was the Perspective from Turner entitled, "ClinicalTrials.gov, stem cells and 'pay-to-participate' clinical studies" [5]. This article discusses how US clinics and international businesses that engage in direct-to-consumer advertising of purported stem cell treatments are successfully registering for-profit, pay-to-participate 'studies' on the NIH registry and database, ClinicalTrials.gov. Turner identified a number of registered studies involving the administration of autologous stem cell interventions that failed to disclose that individuals are charged to participate. This article deals with a very timely issue and shines a light on the current landscape and therefore received attention from numerous news outlets and blog authors from around the world, which contributed to its high Altmetric score.

Special mention goes to the following articles which were some of the most read articles published in Regenerative Medicine in 2017: 


\section{Readership demographics}

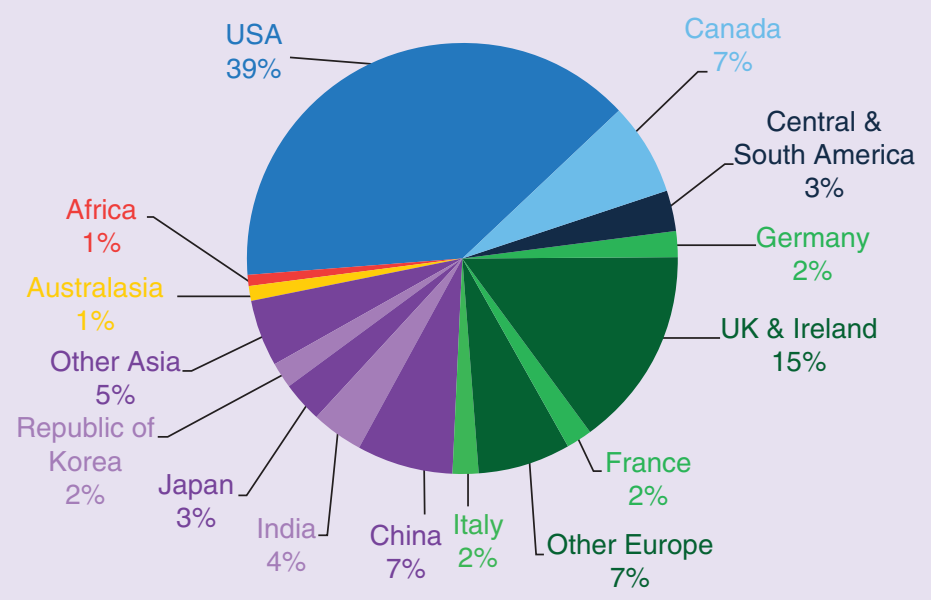

Figure 1. Proportion of readership demographics for Regenerative Medicine in 2017.

- The Special Report entitled, "Contributions for classification of platelet rich plasma-proposal of a new classification: MARSPILL" [6].

- The Clinical Trial Report, "Efficacy and safety of autologous cell therapies for knee cartilage defects (autologous stem cells, chondrocytes or the two): randomized controlled trial design" [7].

- The Perspective entitled, "The European General Data Protection Regulation: challenges and considerations for iPSC researchers and biobanks" [8].

\section{Special Focus Issue}

The aim of special focus issues published in Regenerative Medicine is to highlight key themes and 'hot-topics' in the field. A two-part Special Focus Issue entitled "Regenerative Medicine in Society: Interdisciplinary Perspectives" was published in the September [9] and October [10] 2017 issues of the journal. This expansive collection offers perspectives on key social, ethical, policy and regulatory issues across many areas of the rapidly evolving field of regenerative medicine.

The Special Focus Issue was guest edited by Achim Rosemann (University of Warwick, UK), Jan Barfoot and Clare Blackburn (both MRC Centre for Regenerative Medicine, University of Edinburgh, UK). Through the involvement of Barfoot and Blackburn, the European Commission-funded EuroStemCell project, which aims to educate the public on stem cells and their impact on society, collaborated with Regenerative Medicine toward the publication of these issues.

The guest editors provide scene-setting forewords for both instalments of the two-part Special Focus Issue [11,12], in which they discuss the importance of informing and engaging relevant stakeholders and how this Special Focus Issue aims to facilitate this. They subsequently provide an overview of the wide variety of work presented in each issue including original research, perspectives and commentaries.

The two-part Special Focus Issue was received well within the field and a number of the aforementioned popular articles from 2017 were in fact published in these issues [4-5,8].

\section{Readership demographics}

As the regenerative medicine research community continues to grow, the readership of Regenerative Medicine changes. In 2016, journal content was most read by experts in the USA (39\%) and the UK \& Ireland (15\%; see Figure 1). While Regenerative Medicine content continues to have impact across Europe and the West, we expect to see a continued growth in emerging scientific communities and look forward to continuing the circulation of our content to an increasingly global audience. 


\section{Social media}

Regenerative Medicine's social media presence has continued to grow throughout 2017. We were delighted to celebrate reaching over 2000 followers on the journal's Twitter account (@Regen_Med) [13] and this number has continued to rise. The journal also has a LinkedIn group, open to all [14]. Across these platforms, we regularly post journal highlights including newly published content, issues released, offers and the latest news in the field.

\section{RegMedNet}

As many readers will be aware, Regenerative Medicine is proud to be partnered with and work alongside RegMedNet [15], a free-to-access networking site aiming to promote global collaboration between all members of the diverse regenerative medicine field. RegMedNet aims to provide up-to-date, essential research and information on all aspects of regenerative medicine, from the bench to the bedside. RegMedNet offers easy access to breaking news, exclusive features, interviews, video content, webinars and peer-reviewed journal articles from Regenerative Medicine.

A prime example of this collaborative effort in 2017 is that upon publication of the aforementioned paper by Turner on pay-to-participate stem cell studies in Regenerative Medicine [4], RegMedNet not only offered free access to the full article to all RegMedNet members [16], but it also published an exclusive interview with the author where he discusses the importance of this 'hot topic' within the field [17]. This interview was in fact the second most popular feature published on RegMedNet in 2017. The partnership with RegMedNet therefore provides us the opportunity to further showcase and disseminate work published in Regenerative Medicine across multiple platforms and to a wider audience, potentially adding great benefit to our authors and drive their influence in the field.

Another stand-out feature on RegMedNet in 2017 was an interview with Masayo Takahashi, Project Leader for the Laboratory for Retinal Regeneration at the RIKEN Centre for Developmental Biology (Kobe, Japan). In this interview, Takahashi discusses the techniques being utilized for targeting age-related macular degeneration in the first in-human iPSC clinical trial [18].

\section{The RegMedNet Award for Cultivating Excellence}

In 2017, RegMedNet, in partnership with Regenerative Medicine, established the Award for Cultivating Excellence. In the belief that that the most valuable players in regenerative medicine are not always those seen in the news, the aim of the Award for Cultivating Excellence is to recognize achievement in the field by celebrating any labs/groups that promote career development, undergraduate training, collaboration, innovative research and public outreach.

Nominations were made open to the public and in order to select a winner, a five-nominee shortlist was presented to a panel of international judges made up of Regenerative Medicine Associate Editor Glyn Stacey (International Stem Cell Banking Initiative, UK), Regenerative Medicine editorial board member Alain Vertes (NxR Biotechnologies, Switzerland), Kevin McCormack (California Institute of Regenerative Medicine, CA, USA) and Maneesha Inamdar (Jawaharlal Nehru Centre for Advanced Scientific Research, India).

The winner of the inaugural Award for Cultivating Excellence was the laboratory, Cells for Sight (University College London; UCL, UK), led by Professor Julie T Daniels, which impressed the panel of judges with its support of career development and continued education of the members of the lab [19]. Cells for Sight was established with the aim of researching, developing and delivering safe and effective therapies for the prevention and treatment of blinding eye disorders. The program is a collaboration between the research group of Professor Daniels at UCL Institute of Ophthalmology and clinicians at Moorfields Eye Hospital NHS Foundation Trust (London, UK).

To highlight the achievements of Cells for Sight, they were the subject of a one month-long special feature on RegMedNet [20], featuring interviews with lab members and selected published research. They also received a one year-long subscription to a Future Science Group title of their choice, and 50\% off open access fees for up to five articles published in Regenerative Medicine.

Applications for the 2018 RegMedNet Award for Cultivating Excellence award will open in spring 2018.

\section{Conference attendance}

As we do every year, in 2017, members of the Regenerative Medicine department attended a number of conferences, meetings and events around the world in order to meet our readers, authors, editorial board members and collaborators, as well as keep up to date with the field and ensure that we are covering all the latest and groundbreaking research. In 2017, we attended the following events: 
- International Society for Stem Cell Research (ISSCR) - Translational Opportunities in Stem Cell Research, 27 February-01 March 2017 (Basel, Switzerland).

- International Society for Cellular Therapy (ISCT) - Annual Meeting, 03 May-06 May 2017 (London, UK).

- World Advanced Therapies \& Regenerative Medicine Congress 2017, 17 May-19 May 2017 (London, UK).

- Regenerative Medicine in the UK Health System: Challenges, Prospects and Readiness, 23 May 2017 (London, UK).

- ISSCR - Annual Meeting, 14 June-17 June 2017 (Boston, MA, USA).

- Alliance for Regenerative Medicine - 5th Annual European Advanced Therapies Investor Day, 09 November 2017 (London, UK).

- Better Science, Better Health: Advanced Therapies - Opportunities and Challenges, 14 November 2017 (London, $\mathrm{UK})$.

In order to keep up-to-date on which events the Regenerative Medicine team will be attending in 2018, please follow the journal on Twitter [13], join our LinkedIn group [14] or become a member of RegMedNet for free [15].

\section{Conclusion}

We appreciate all feedback from the regenerative medicine community regarding the direction of our content, especially suggestions of any priority topics in the field that you feel the journal should cover. We welcome unsolicited research, review and opinion article proposals, among others, and would be delighted to hear from you if you are interested in submitting to the journal.

I would also like to take this opportunity to thank our readers, contributing authors, valued Editorial Board members and peer reviewers for their continued support and collaboration as we continue to publish the latest cutting-edge research. We very much look forward to working with you all over the next year and hope to see Regenerative Medicine continue to grow and serve the research community in 2018.

\section{Financial \& competing interests disclosure}

A Price-Evans is an employee of Future Science Ltd, publisher of Regenerative Medicine. The author has no other relevant affiliations or financial involvement with any organization or entity with a financial interest in or financial conflict with the subject matter or materials discussed in the manuscript apart from those disclosed.

No writing assistance was utilized in the production of this manuscript.

\section{References}

1. Future Medicine. Special focus issue: regenerative medicine: past, present and future. Regen. Med. (2016). www.futuremedicine.com/toc/rme/11/8

2. Gonzalez-Garza MT, Cruz-Vega DE. Regenerative capacity of autologous stem cell transplantation in elderly: a report of biomedical outcomes. Regen. Med. 12(2), 169-178 (2017).

3. Shyam H, Singh SK, Kant R, Saxena SK. Mesenchymal stem cells in regenerative medicine: a new paradigm for degenerative bone diseases. Regen. Med. 12(2), 111-114 (2017).

4. Marcon AR, Murdoch B, Caulfield T. Fake news portrayals of stem cells and stem cell research. Regen. Med. 12(7), 765-775 (2017).

5. Turner L. ClinicalTrials.gov, stem cells and 'pay-to-participate' clinical studies. Regen. Med. 27(6), 705-719 (2017).

6. Lana JFSD, Purita J, Paulus C et al. Contributions for classification of platelet rich plasma - proposal of a new classification: MARSPILL. Regen. Med. 12(5), 565-574 (2017).

7. Richardson JB, Wright KT, Wales J et al. Efficacy and safety of autologous cell therapies for knee cartilage defects (autologous stem cells, chondrocytes or the two): randomized controlled trial design. Regen. Med. 12(5), 493-501 (2017).

8. Morrison M, Bell J, George C, Harmon S, Munsie M, Kaye J. The European General Data Protection Regulation: challenges and considerations for iPSC researchers and biobanks. Regen. Med. 12(6), 693-703 (2017).

9. Future Medicine. Special Focus Issue on regenerative medicine in society: interdisciplinary perspectives (part I). Regen. Med. (2017). www.futuremedicine.com/toc/rme/12/6

10. Future Medicine. Special Focus Issue on regenerative medicine in society: interdisciplinary perspectives (part II). Regen. Med. (2017). www.futuremedicine.com/toc/rme/12/7

11. Rosemann A, Barfoot J, Blackburn C. Special Focus Issue on regenerative medicine in society: interdisciplinary perspectives (part I) Foreword. Regen. Med. 12(6), 577-580 (2017).

12. Barfoot J, Rosemann A, Blackburn C. Special Focus Issue on regenerative medicine in society: interdisciplinary perspectives (part II) Foreword. Regen Med. 12(7), 733-736 (2017). 
13. Regen Med. Twitter. https://twitter.com/Regen_Med

14. Regenerative Medicine (the purple journal). LinkedIn. www.linkedin.com/groups/4383090

15. Reg. Med. Net.. www.regmednet.com

16. ClinicalTrials.gov, stem cells and pay-to-participate clinical studies. Reg. Med. Net. (2017). www.regmednet.com/users/1122regenerative-medicine/posts/18532-clinicaltrials-gov-stem-cells-and-pay-to-participate-clinical-studies

17. "Pay-to-participate" stem cells studies: an interview with Leigh Turner. Reg. Med. Net.www.regmednet.com/users/1122-regenerativemedicine/posts/18659-pay-to-participate-stem-cells-studies-an-interview-with-leigh-turner

18. Speaking with Masayo Takahashi: Targeting age-related macular degeneration in the first iPSC clinical trial. Reg. Med. Net. (2017). www.regmednet.com/users/24427-freya-leask/posts/14546-targeting-age-related-macular-degeneration-in-the-first-ipsc-clinical-trialan-interview-with-masayo-takahashi

19. EurekAlert! RegMedNet announces winner of the first Award for Cultivating Excellence (2017). www.eurekalert.org/pub_releases/2017--11/fsg-ra111417.php

20. Award for Cultivating Excellence 2017 - Winner's Spotlight (2017).

www.regmednet.com/channels/1437-award-for-cultivating-excellence-2017-winner-s-spotlight 